\title{
Effects of Interferon- $\gamma$ on Nitric Oxide Synthase Activity and Endothelin-1 Production by Vascular Endothelial Cells
}

\author{
Santiago Lamas, ${ }^{*}$ Thomas Michel, ${ }^{*}$ Tucker Collins, ${ }^{5}$ Barry M. Brenner, ${ }^{\star}$ and Philip A. Marsden ${ }^{\star \|}$ \\ ${ }^{*}$ Renal and ${ }^{\ddagger}$ Cardiology Divisions of the Department of Medicine, Brigham and Women's Hospital and Harvard Center for the Study of \\ Kidney Diseases, Harvard Medical School, Boston, Massachusetts 02114; ${ }^{\S}$ Vascular Research Division, Department of Pathology, \\ Brigham and Women's Hospital, Harvard Medical School, Boston, Massachusetts 02114; and "Renal Division and Department of \\ Medicine, St. Michael's Hospital, University of Toronto, Toronto, Ontario M5S 1A8, Canada
}

\begin{abstract}
Given the pivotal role suggested for IFN- $\gamma$ in immune diseases of the vascular wall, we investigated the effects of IFN- $\gamma$ on nitric oxide (NO) and endothelin-1 (ET-1) expression in bovine aortic endothelial cells (BAEC). We have previously reported that TNF- $\alpha$ enhanced NO synthase activity in BAEC as assessed by quantifying release of bioactive $\mathrm{NO}$ with reporter monolayers and measuring conversion of $\mathrm{L}-\left[{ }^{14} \mathrm{C}\right]$ arginine to $\mathrm{L}$ $\left[{ }^{14} \mathrm{C}\right]$ citrulline. In murine macrophages IFN- $\gamma$ synergizes with TNF- $\alpha$ or lipopolysaccharide to induce robust increases in calcium-independent NO synthase activity. In this study we have found that IFN- $\gamma$ alone failed to have a significant effect on NO synthase activity in BAEC. In contrast to murine macrophages, IFN- $\gamma$ inhibited TNF- $\alpha$-stimulated induction of endothelial NO synthase activity in a concentration-dependent manner. This observation suggests that there is major difference in the response of BAEC and murine macrophages to IFN- $\gamma$.

A second major aim of this study was to determine the effect of IFN- $\gamma$ on preproET-1 mRNA expression and ET-1 secretion rates in BAEC. IFN- $\gamma$ alone had little or no effect on ET-1 mRNA levels and basal ET release when measured for $8 \mathrm{~h}$. However, cotreatment with IFN- $\gamma$ potentiated the stimulatory effect of TNF- $\alpha$ on BAEC ET-1 mRNA transcript levels and ET release. In contrast, pretreatment of cells with IFN- $\gamma$ for 16-24 h blunted the stimulatory effect of TNF- $\alpha$. These findings suggest that endothelial cell expression of vasoactive mediators is modified by the temporal interplay of at least two immune mediators, IFN- $\gamma$ and TNF- $\alpha$. (J. Clin. Invest. 1992. 90:879-887.) Key words: atherosclerosis • cytokines $\bullet$ endothelium • endothelium-derived relaxing factor • vasoconstrictor • vasodilator
\end{abstract}

\section{Introduction}

It has recently been appreciated that the vascular endothelium participates in the paracrine control of vascular tone and function through the release of potent vasodilator and vasoconstrictor mediators (1).

Nitric oxide (NO) accounts for a major component of the biological activity of endothelium-derived relaxing factor. Regulation of NO synthase(s) activity appears to be a key regula-

Address reprint requests to Dr. Marsden, Room 7360, Medical Sciences Building, University of Toronto, 1 King's College Circle, Toronto, Ontario M5S 1A8, Canada.

Received for publication 9 December 1991 and in revised form 19 March 1992.

J. Clin. Invest.

(c) The American Society for Clinical Investigation, Inc. 0021-9738/92/09/0879/09 \$2.00

Volume 90, September 1992, 879-887 tory process in the production of NO from L-arginine. Current concepts suggest that NO synthase exists as at least two discrete families of isoforms: a constitutive calcium/calmodulin-dependent NO synthase and a cytokine-induced calcium-independent NO synthase (2). Cell types expressing the former pathway include cerebellum $(3,4)$ and endothelial cells $(5)$, whereas macrophages (5-7), neutrophils (8), Kupffer cells (9), hepatocytes (10), vascular smooth muscle (11-13), and glomerular mesangial cells $(13,14)$ are examples of cell types known to express the latter. For example, the proinflammatory cytokine tumor necrosis factor- $\alpha(\mathrm{TNF}-\alpha)^{1}$ induces expression of NO synthase activity in bovine mesangial and vascular smooth muscle cells (13). Recently several laboratories, including our own, provided evidence for coexpression of different NO synthase isoforms in the same cell type $(15,16)$. TNF$\alpha$ or lipopolysaccharide (LPS) treatment induced calcium-independent NO synthesis in bovine aortic and renal artery endothelial cells (15), cells that clearly expressed calcium-regulated release of NO under basal conditions.

The exogenous stimuli that regulate NO synthase activity in various cell types is an exciting field of study of great relevance to diseases of the vascular wall. For instance, induction of NO synthase ( $\mathrm{s}$ ) in vascular wall cells by cytokines and LPS may play an important role in the pathogenesis of sepsis-related hypotension $(17,18)$. The lymphokine interferon- $\gamma$ $(\mathrm{IFN}-\gamma)$ is known to have potent effects on endothelial phenotype (19) and has been implicated as an important mediator in immune diseases of the vascular wall. In the current study we determined the effect of IFN- $\gamma$ on basal and TNF- $\alpha$-stimulated NO production in bovine aortic endothelial cells (BAEC). We provide evidence that IFN- $\gamma$ inhibits TNF- $\alpha-$ stimulated, but not calcium agonist-induced, NO production by aortic endothelial cells. This is a surprising finding because IFN- $\gamma$ is synergistic with LPS or TNF- $\alpha$ as inducers of NO synthase activity in murine macrophages. TNF- $\alpha$ is without a significant effect unless macrophages are cotreated with IFN- $\gamma$. This observation suggests that there is a major difference in the response of BAEC and murine macrophages to the cytokine IFN- $\gamma$.

Endothelin-1 (ET-1) is a 21-amino acid peptide which was initially purified from the culture medium of aortic endothelial cells (20). Local release and paracrine action of ET-1 presumably represents a local cardiovascular control pathway. Of relevance to the current study, cytokine action on the vascular wall

1. Abbreviations used in this paper: BAEC, bovine aortic endothelial cells; ET-1, endothelin-1; GMC, glomerular mesangial cells; IBMX, 3-isobutyl-1-methylxanthine; LDH, lactate dehydrogenase; rBo-, recombinant bovine; rHu-, recombinant human; TNF, tumor necrosis factor. 
has also been implicated in the regulation of ET-1 expression (21). Prior studies have demonstrated that TNF- $\alpha$ enhanced endothelial release of ET-1 and increased ET-1 mRNA levels. This latter process was mediated by enhanced transcription as indicated by nuclear run-off analysis (22). Interleukin- $1 \beta$ and LPS mimicked this effect (22-24). In this study we have examined the modulatory effect of IFN- $\gamma$ on ET-1 expression. We report that IFN- $\gamma$ potentiated the stimulatory effect of TNF- $\alpha$ on ET-1 release and preproET-1 mRNA accumulation in aortic endothelial cells over a 4-8-h period. In contrast, IFN- $\gamma$ had no effect in the absence of concurrent TNF- $\alpha$ treatment. Given that IFN- $\gamma$ pretreatment blocks TNF- $\alpha$-stimulated induction of NO synthase activity we defined the effect of this pretreatment on ET-1 expression. Of interest, pretreatment of endothelial cells with IFN- $\gamma$ inhibits TNF- $\alpha$-stimulated increases in ET-1 expression.

\section{Methods}

Materials. Cell culture media were purchased from Gibco Laboratories, Grand Island, NY; low endotoxin-defined supplemented bovine calf serum from Hyclone Laboratories, Logan, UT; guanosine 3,5'cyclic monophosphate (cGMP) radioimmunoassay from Biomedical Technologies, Stoughton, MA; cell culture plates from Costar, Cambridge, MA; glass coverslips from Bellco Biotechnology, Vineland, NJ; human recombinant TNF- $\alpha$ (rHuTNF- $\alpha$, sp act $9.8 \times 10^{6} \mathrm{U} / \mathrm{mg}$ ) was a gift of Knoll Pharmaceuticals, Whippany, NJ; bovine recombinant IFN- $\gamma\left(\mathrm{rBoIFN}-\gamma, 4.1 \times 10^{6} \mathrm{U} / \mathrm{mg}\right)$ was a gift of CIBA-GEIGY, Basel, Switzerland. L- $\left[\mathrm{U}-{ }^{14} \mathrm{C}\right]$ arginine (sp act $305 \mathrm{mCi} / \mathrm{mmol}$ ) was from Amersham Corp., Arlington Heights, IL. Dowex AG 50WX-8 cation exchange resin (100-200 mesh) was from Bio-Rad Laboratories, Richmond, CA. Thin-layer chromatography (TLC) silica gel 60 plates were from Alltech Associates Inc., Deerfield, IL. Sep-Pak $\mathrm{C}_{18}$ extraction columns were from Water Associates, Milford, MA; X-OMAT AR X-ray film was from Eastman Kodak Co., Rochester, NY. Deoxycytidine 5 'triphosphate $\left[\alpha{ }^{32} \mathrm{P}\right]-(3,000 \mathrm{Ci} / \mathrm{mmol})$ and ${ }^{125} \mathrm{I}-\mathrm{Tyr}^{13}$-ET-1 $(2,200$ $\mathrm{Ci} / \mathrm{mmol}$ ) were from DuPont-New England Nuclear, Wilmington, DE. ET-1 was from Peptides International Inc., Louisville, KY. Guanidinium thioocyanate was from Fluka BioChemika, Buchs, Switzerland; phenol ( molecular grade) from Boehringer Mannheim Biochemicals, Indianapolis, IN; L-arginine, 3-isobutyl-1-methylxanthine (IBMX), L-arginine, L-citrulline, lithium chloride, and all other reagents were purchased from Sigma Chemical Co., St. Louis, MO.

Cell isolation and culture. BAEC were isolated from bovine thoracic aorta using published methods (25). Individual clones were examined for angiotensin I-converting enzyme activity, expression of factor VIII-related antigen, and uniform uptake of fluorescent acetylated LDL, as described (25). Fluorescence-activated cell sorting (FACS) of clones labeled with fluorescent acetylated LDL confirmed that endothelial cell clones represented homogeneous populations of cells that were both uniformly labeled and clearly distinguishable from cloned populations of vascular smooth muscle cells. Working concentrations of rHuTNF- $\alpha$, rBoIFN- $\gamma$, and culture medium contained $<10 \mathrm{pg} / \mathrm{ml}$ of endotoxin as determined by a semiquantitative E-Toxate assay kit (Sigma Chemical Co.). Trypan blue dye exclusion and measurement of lactate dehydrogenase enzymatic (LDH) activity (Kodak Ektachem quantitative kinetic determination, Eastman Kodak Co.) in culture cell supernatants confirmed that treatment of endothelial cells with rBolFN- $\gamma$ and/or rHuTNF- $\alpha$ at concentrations similar to those used in this study failed to produce significant cellular toxicity ( $>95 \%$ trypan blue exclusion for IFN- $\gamma-(1,000 \mathrm{U} / \mathrm{ml}, 48 \mathrm{~h}), \mathrm{TNF}-\alpha-(100 \mathrm{ng} /$ $\mathrm{ml}, 24 \mathrm{~h}$ ), and $>90 \%$ exclusion for IFN- $\gamma /$ TNF- $\alpha$-treated-BAEC, respectively; $3.8 \pm 0.2,3.3 \pm 0.2$, and $10.8 \pm 0.2 \%$ of $L D H$ release using Triton X-100 as a positive control $(100 \%)$ for IFN- $\gamma-(1,000 \mathrm{U} / \mathrm{ml}, 48$ h), TNF- $\alpha-(100 \mathrm{ng} / \mathrm{ml}, 24 \mathrm{~h})$, and IFN- $\gamma / \mathrm{TNF}-\alpha$-treated BAEC ( $n$ $=6$ ), respectively).

Determination of $L-\left[{ }^{14} \mathrm{C}\right]$ citrulline formation. BAEC grown in sixwell plates were kept in serum-free culture medium for $48 \mathrm{~h}$ before assay and L-arginine-free culture medium for $4 \mathrm{~h}$. L- $\left[{ }^{14} \mathrm{C}\right]$ arginine $\left(0.25-1.0 \times 10^{6} \mathrm{cpm} / \mathrm{ml}, 0.4-1.5 \mathrm{nmol} / \mathrm{ml}\right)$, purified by TLC, was added as indicated. The reaction was stopped by addition of ice-cold $15 \%$ TCA to the well. Samples were extracted as described (15) and applied to 2-ml wet bed volumes of Dowex AG 50WX-8 ( $\mathrm{Li}^{+}$form), followed by $2 \mathrm{ml}$ of water. $\mathrm{L}-\left[{ }^{14} \mathrm{C}\right]$ Citrulline was quantitated in the 4-ml column effluent. TLC was utilized to validate the product of cation-exchange chromatography using published methods (15). Aliquots $(10 \mu \mathrm{l})$ of sample were resolved on TLC silica gel 60 plates (chloroform/methanol/ammonium hydroxide/water 1:4:2:1 vol/vol). $R_{\mathrm{f}}$ values determined for L-arginine and L-citrulline were $0.42 \pm 0.04$ and $0.86 \pm 0.03$, respectively $(n=3)$. Product and reference standards were localized with $\mathrm{EN}^{3} \mathrm{HANCE}$ spray (New England Nuclear, Dupont, Boston, MA). After autoradiography and scraping the samples were quantitated by scintillation counting.

Quantitation of $c G M P$. Methodology for this bio-assay has been described in detail previously (25). Rat glomerular mesangial cell (GMC) cultures were established and maintained as described (15). Briefly, BAEC and GMC were replicate-plated on 12-well tissue culture plates and 12-mm glass coverslips, respectively. BAEC were kept in serum-free medium for $48 \mathrm{~h}$ before assay. GMC were kept in serumfree medium for $24 \mathrm{~h}$ before assay. Coverslips of GMC were removed from 24-well plates and placed inverted on BAEC monolayers. Cells were allowed to equilibrate for $1 \mathrm{~h}$ at $37^{\circ} \mathrm{C}$ in $1 \mathrm{ml}$ of incubation buffer composed of $130 \mathrm{mM} \mathrm{NaCl}, 5 \mathrm{mM} \mathrm{KCl}, 10 \mathrm{mM}$ D-glucose, $1 \mathrm{mM}$ $\mathrm{MgCl}_{2}, 1.5 \mathrm{mM} \mathrm{CaCl}_{2}, 25 \mathrm{mM}$ Hepes ( $\mathrm{pH} 7.4$ ), and $1 \mathrm{mM} \mathrm{L}$-arginine. $\operatorname{IBMX}(1 \mathrm{mM})$ was added $10 \mathrm{~min}$ before termination of the assay and additions were made directly to the coincubation assay as indicated. To terminate the assay, coverslips were rapidly removed from the coincubation system and placed into $0.5 \mathrm{ml}$ ice-cold TCA. GMC-associated cGMP was determined by radioimmunoassay as described (15). When BAEC were exposed to cytokines, the indicated time period represents the total time elapsed before TCA extraction of reporter GMC monolayers and includes the $1-\mathrm{h}$ coincubation assay. Control studies not shown demonstrated that $1 \mathrm{~h}$ TNF- $\alpha(100 \mathrm{ng} / \mathrm{ml})$ and IFN- $\gamma(1,000$ $\mathrm{U} / \mathrm{ml}$ ), either alone or in combination, failed to modify the cGMP content of mesangial cells. Furthermore, prior studies from this laboratory have demonstrated that though NO synthase activity can be induced in mesangial cells by TNF- $\alpha$ this response is evident no earlier than $4 \mathrm{~h}$ (13).

ET radiobinding assay. Determinations of ET were performed with a radiobinding assay as previously described (26). Briefly, samples of BAEC-conditioned medium were extracted over Sep-Pak $\mathrm{C}_{18}$ columns, eluted with ethanol- $\mathrm{H}_{2} \mathrm{O}$-acetic acid (90:9.6:0.4), lyophilized, and stored at $-20^{\circ} \mathrm{C}$ before assay. Rat glomerular microsomes bearing specific high-affinity endothelin binding sites were used as a binding fraction for a competitive radioligand binding assay. Recovery of ET-1 was $>90 \%$. Inter- and intrassay variability are 11.7 and $6.0 \%$, respectively. Conditions were measured in triplicate and each sample three times. Experiments were repeated on at least three occasions.

RNA isolation, Northern blotting, and hybridization. Total cellular RNA was isolated from BAEC with the guanidinium thiocyanatephenol-chloroform method (27), size-fractionated by electrophoresis (10 $\mu \mathrm{g} /$ lane) through denaturing $1 \%$ agarose- $0.66 \mathrm{M}$ formaldehyde gels, transferred to Magnagraph hybridization transfer membrane (Micron Separations, Westborough, MA), UV cross-linked, and hybridized as previously described (26).

cDNA clones. A full-length bovine preproET-1 cDNA was isolated from a $\lambda g t 11$ bovine aortic endothelial cell cDNA library (Clontech, Palo Alto, CA) by plaque hybridization using a ${ }^{32} \mathrm{P}$-labeled $1.2 \mathrm{kB}$ human ET-1 cDNA. The isolation and characterization of this human ET-1 cDNA has been described (26). 10 cross-hybridizing phage clones were isolated from $2.5 \times 10^{5}$ plaques screened. One of these 
clones was further characterized. A full-length bovine ET-1 cDNA (1.4-kb EcoR I restriction fragment) was purified by preparative agarose gel electrophoresis, subcloned in $\mathrm{pBS}(+)$, subjected to dideoxy chain-termination sequence analysis of both chains with Sequenase 2.0 (US Biochemical Corp., Cleveland, $\mathrm{OH}$ ), and found to be in agreement with the published bovine preproET-1 cDNA sequence (28). To control for the amount of RNA loaded per lane, blots were rehybridized with a rat $\beta$-tubulin cDNA (1.1 kB BamH I-Pst I insert) (29). The density of autoradiographic signals was quantitated with a model MSF-300GS image scanner (Microtek Lab Inc., Torrance, CA) using the software package Image 1.31. Unless otherwise stated Northern blot studies are representative of three similar experiments.

Data analysis. Unless otherwise indicated, data are expressed as the mean $\pm \mathrm{SE}$ obtained in at least three separate experiments. Comparisons were made with analysis of variance followed by Dunnett's modifcation of the $t$ test whenever comparisons were made with a common control and the unpaired two-tailed Student's $t$ test for other comparisons. The level of statistically significant difference was defined as $P$ $<0.05$.

\section{Results}

IFN- $\gamma$ inhibits $T N F$ - $\alpha$-induced release of bioactive $N O$. The release of $\mathrm{NO}$ was detected in a coincubation bioassay where measurement of cGMP production in reporter monolayers of GMC reflected activation of soluble guanylate cyclase. Fig. 1

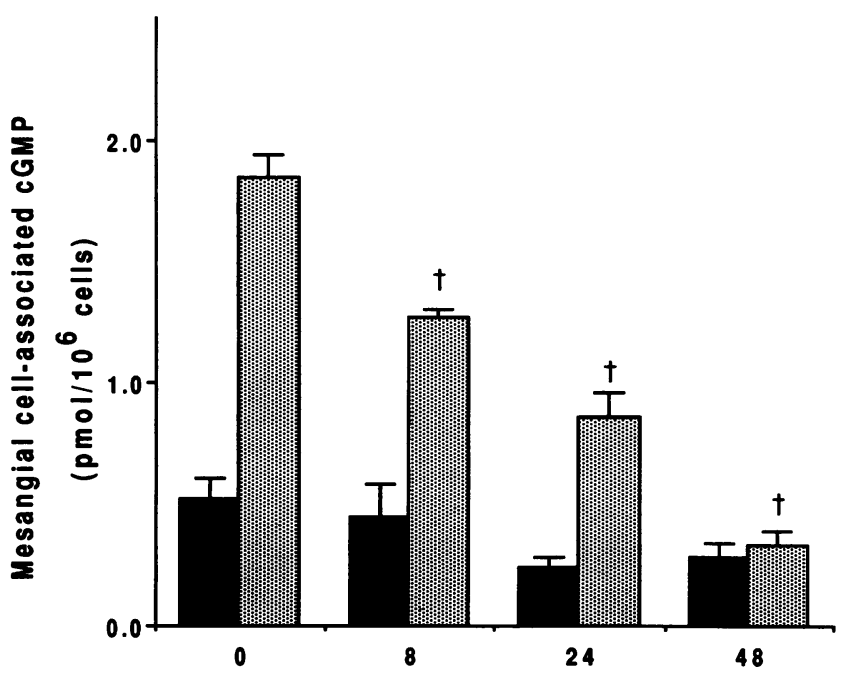

TIME of IFN- $\gamma$ treatment (h)

Figure 1. Effect of IFN- $\gamma$ on TNF- $\alpha$-stimulated BAEC-dependent increases in GMC-associated cGMP content. In this coincubation assay monolayers of GMC, grown on coverslips, and monolayers of BAEC, grown on 12-well plates, are physically juxtaposed for $1 \mathrm{~h}$. The coincubation system was treated with $1 \mathrm{mM}$ IBMX 10 min before extraction of cGMP from mesangial cells. Columns represent mesangial cell-associated cGMP in the presence of vehicle- (solid bars) or TNF- $\alpha$-treated (rHuTNF- $\alpha, 100 \mathrm{ng} / \mathrm{ml}, 24 \mathrm{~h}$ ) BAEC (gray bars). BAEC were treated for the indicated periods with rBoIFN- $\gamma$ $(1,000 \mathrm{U} / \mathrm{ml})$. Indicated times represent that period in which BAEC were exposed to cytokines before TCA extraction of GMC, and includes the $1-\mathrm{h}$ coincubation period. Columns represent mean $\pm \mathrm{SE}$ of three experiments, triplicate determinations. ${ }^{\dagger} P<0.05$ vs. TNF- $\alpha-$ treated BAEC in the absence of IFN- $\gamma$. In the absence of BAEC, GMC cGMP levels averaged $0.29 \pm 0.06 \mathrm{pmol} / 10^{6}$ cells. demonstrates that reporter monolayer cGMP content was greater in the presence of TNF- $\alpha$-treated (rHuTNF- $\alpha 100 \mathrm{ng} /$ $\mathrm{ml}, 24 \mathrm{~h}$ ) BAEC than in the presence of vehicle-treated BAEC. Stated in other terms, BAEC treated with TNF- $\alpha$ for $24 \mathrm{~h}$ released more bioactive NO than vehicle-treated cells. This is consistent with our prior published results suggesting that TNF- $\alpha$ enhanced release of NO from BAEC (15). In this prior study, TNF- $\alpha$-stimulated increases in the release of bioactive NO required treatment of BAEC with TNF- $\alpha$ for at least $8 \mathrm{~h}$ and were maximal after $24 \mathrm{~h}$ of TNF- $\alpha$ treatment.

In the present study, BAEC monolayers were treated with rBoIFN- $\gamma(1,000 \mathrm{U} / \mathrm{ml})$ for 8,24 , and $48 \mathrm{~h}$. These additions were made to two groups of BAEC; cells that were treated with TNF- $\alpha$ (rHuTNF- $\alpha 100 \mathrm{ng} / \mathrm{ml})$ or vehicle for $24 \mathrm{~h}$. Indicated times represent the period in which BAEC were exposed to the relative agents. This time period includes the $1-\mathrm{h}$ period of coincubation with reporter monolayers. Fig. 1 demonstrates that in the absence of TNF- $\alpha$ ( solid bars) addition of IFN- $\gamma$ for 8,24 , or $48 \mathrm{~h}$ failed to have a significant effect on reporter monolayer cGMP content. Though levels of reporter cGMP content tended to decrease at 24 and $48 \mathrm{~h}$ this effect did not reach significance. In contrast, addition of IFN- $\gamma$ for 8,24 , and $48 \mathrm{~h}$ to TNF- $\alpha$-treated BAEC (gray bars) markedly decreased reporter cGMP content compared to mesangial cells coincubated with TNF- $\alpha$-treated BAEC that were not exposed to IFN- $\gamma$. Therefore, though IFN- $\gamma$ alone failed to have a significant effect on release of bioactive NO from BAEC it markedly inhibited TNF- $\alpha$-stimulated release. This observed inhibition was most evident when BAEC monolayers were pretreated with IFN- $\gamma$, that is to say when IFN- $\gamma$ was added before TNF- $\alpha$ (i.e., 48-h IFN- $\gamma / 24-h$ TNF- $\alpha$ compared to $24-h$ TNF- $\alpha$ ). Inhibition of NO release by IFN- $\gamma$ was also evident when IFN- $\gamma$ and TNF- $\alpha$ were added simultaneously (i.e., 24-h IFN- $\gamma / 24-h$ TNF- $\alpha$ compared to 24 -h TNF- $\alpha$ ), or when IFN- $\gamma$ was added after TNF- $\alpha$ addition (i.e., 8-h IFN- $\gamma / 24-h$ TNF- $\alpha$ compared to $24-h \mathrm{TNF}-\alpha$ ). It is important to note that, though GMC reporter monolayers were exposed to the indicated cytokines for $1 \mathrm{~h}$ before TCA extraction, in control studies not shown, we demonstrated that $1-\mathrm{h}$ TNF- $\alpha(100 \mathrm{ng} / \mathrm{ml})$ and IFN- $\gamma(1,000$ $\mathrm{U} / \mathrm{ml}$ ), either alone or in combination, failed to modify the cGMP content of GMC. These were important controls to perform because prior studies from this laboratory have demonstrated that NO synthase activity can be induced in GMC by TNF- $\alpha$, though this response is evident no earlier than $4 \mathrm{~h}(13)$.

IFN- $\gamma$ inhibits $T N F-\alpha$-induced production of $\left[{ }^{14} C\right]-$ citrulline from $\left[{ }^{14} \mathrm{C}\right]$ arginine in $B A E C$. Given that $\mathrm{L}$-arginine serves as a substrate for NO synthase and that TNF- $\alpha$ stimulates production of $\mathrm{L}-\left[{ }^{14} \mathrm{C}\right]$ citrulline from $\mathrm{L}-\left[{ }^{14} \mathrm{C}\right]$ arginine in BAEC (15), we determined the effect of IFN- $\gamma$ on citrulline formation in BAEC. As in our prior work, quantitation of $\mathrm{L}$ $\left[{ }^{14} \mathrm{C}\right]$ citrulline includes both medium and cell-associated radioactivity and therefore represent total well production. Shown in Fig. 2 , TNF- $\alpha(100 \mathrm{ng} / \mathrm{ml}, 24 \mathrm{~h})$ augmented production of $\mathrm{L}-\left[{ }^{14} \mathrm{C}\right]$ citrulline from $\mathrm{L}-\left[{ }^{14} \mathrm{C}\right]$ arginine over a 3 -h period. Though IFN- $\gamma(200 \mathrm{U} / \mathrm{ml}, 24 \mathrm{~h})$ had no effect on $\mathrm{L}-\left[{ }^{14} \mathrm{C}\right]-$ citrulline production by itself, it abrogated TNF- $\alpha$-stimulated increases in $\mathrm{L}-\left[{ }^{14} \mathrm{C}\right]$ arginine conversion to $\mathrm{L}-\left[{ }^{14} \mathrm{C}\right]$ citrulline in BAEC.

In Fig. 3, BAEC monolayers were treated with rBoIFN- $\gamma$ $(1,000 \mathrm{U} / \mathrm{ml})$ for 8,24 , and $48 \mathrm{~h}$. These additions were again 


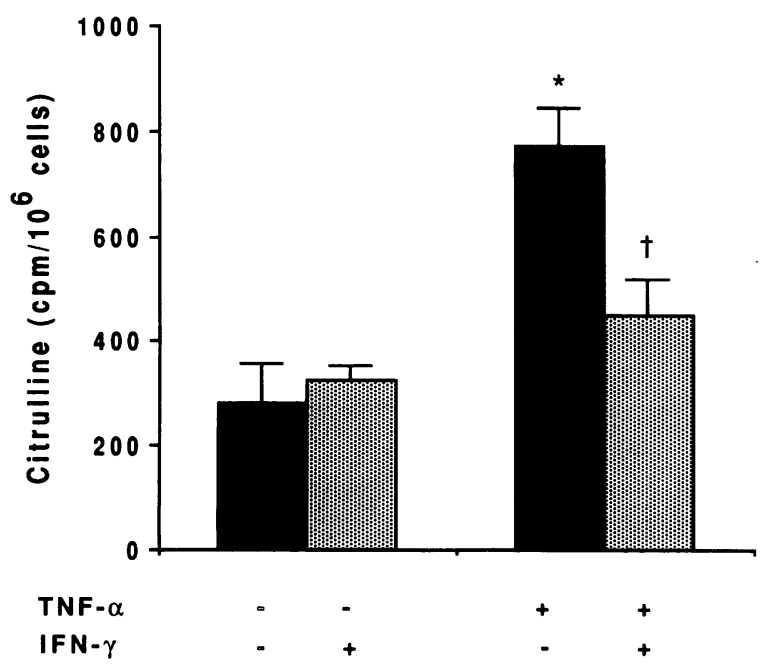

Figure 2. Effect of IFN- $\gamma$ on $\mathrm{L}-\left[{ }^{14} \mathrm{C}\right]$ arginine to $\mathrm{L}-\left[{ }^{14} \mathrm{C}\right]$ conversion in BAEC. L- $\left[{ }^{14} \mathrm{C}\right]$ arginine $\left(3 \times 10^{5} \mathrm{cpm} / \mathrm{ml}\right)$ was added for $3 \mathrm{~h}$ to BAEC grown in six-well plates. Following extraction with $1 \mathrm{ml}$ of ice-cold $15 \%$ TCA, L- $\left[{ }^{14} \mathrm{C}\right]$ citrulline in each well was determined by quantitative cation-exchange chromatography. Columns represent $\mathrm{L}-\left[{ }^{14} \mathrm{C}\right]-$ citrulline formation in vehicle (solid bars) or IFN- $\gamma$-treated BAEC $(200 \mathrm{U} / \mathrm{ml}, 24 \mathrm{~h})($ gray bars $)$ in the presence or absence of TNF- $\alpha$ $(100 \mathrm{ng} / \mathrm{ml}, 24 \mathrm{~h})$. Each point represents means $\pm \mathrm{SE}$ of three experiments, triplicate determinations. ${ }^{*} P<0.05$ vs. control. ${ }^{\dagger} P<0.05$ vs. TNF- $\alpha$-treated BAEC in the absence of IFN- $\gamma$.

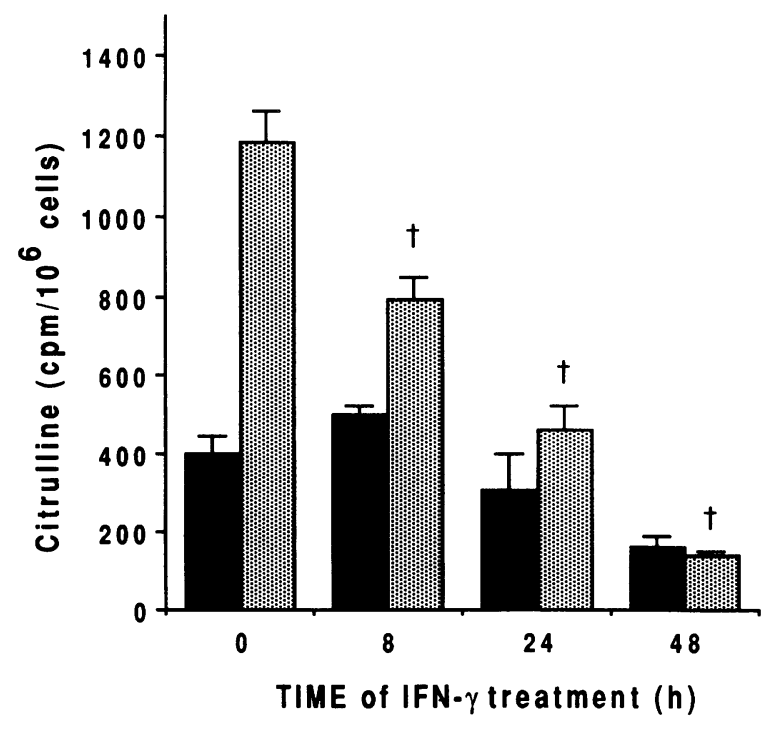

Figure 3. Effect of IFN- $\gamma$ on TNF- $\alpha$-induced augmentation of $\mathrm{L}-\left[{ }^{14} \mathrm{C}\right]-$ arginine to $\mathrm{L}-\left[{ }^{14} \mathrm{C}\right]$ citrulline conversion in BAEC. $\mathrm{L}-\left[{ }^{14} \mathrm{C}\right]$ arginine $(3$ $\times 10^{5} \mathrm{cpm} / \mathrm{ml}$ ) was added for $3 \mathrm{~h}$ to BAEC grown in six-well plates. $\mathrm{L}-\left[{ }^{14} \mathrm{C}\right]$ citrulline in each well was determined by quantitative cation exchange chromatography. Columns represent $\mathrm{L}-\left[{ }^{14} \mathrm{C}\right]$ citrulline formation by vehicle-( solid bars) or TNF- $\alpha$-treated (rHuTNF- $\alpha, 100$ $\mathrm{ng} / \mathrm{ml}, 24 \mathrm{~h}$ ) (gray bars) BAEC. BAEC were treated for the indicated periods with $\mathrm{rBoIFN}-\gamma(1,000 \mathrm{U} / \mathrm{ml})$. Indicated times represent that period in which BAEC were exposed to cytokines before total well TCA extraction. Each point represents means \pm SE of three experiments, triplicate determinations. ${ }^{\dagger} P<0.05$ vs. TNF- $\alpha$-treated BAEC in the absence of IFN- $\gamma$. made to two groups of BAEC; cells that were treated with TNF$\alpha(\mathrm{rHuTNF}-\alpha 100 \mathrm{ng} / \mathrm{ml})$ or vehicle for $24 \mathrm{~h}$. Indicated times represent the period in which BAEC were exposed to the relative agents. Treatment of BAEC with IFN- $\gamma$ for 8 or $24 \mathrm{~h}$, in the absence of TNF- $\alpha$ (solid bars), failed to have a significant effect on $\mathrm{L}-\left[{ }^{14} \mathrm{C}\right]$ arginine conversion to $\mathrm{L}-\left[{ }^{14} \mathrm{C}\right]$ citrulline. Treatment of BAEC with IFN- $\gamma$ for $48 \mathrm{~h}$ tended to decrease $\mathrm{L}-\left[{ }^{14} \mathrm{C}\right]-$ arginine conversion to $\mathrm{L}-\left[{ }^{14} \mathrm{C}\right]$ citrulline at $48 \mathrm{~h}$ though this effect did not reach significance. Consistent with results obtained in the coincubation assay, addition of IFN- $\gamma$ for 8,24 , and $48 \mathrm{~h}$ to TNF- $\alpha$-treated BAEC (gray bars) markedly decreased $\mathrm{L}-\left[{ }^{14} \mathrm{C}\right]$ citrulline formation compared to $\mathrm{L}-\left[{ }^{14} \mathrm{C}\right]-$ citrulline formation by BAEC treated with TNF- $\alpha$ alone. Stated in other terms, Fig. 3 demonstrates that IFN- $\gamma$ inhibited TNF- $\alpha$-stimulated $\mathrm{L}-\left[{ }^{14} \mathrm{C}\right]$ citrulline production whether BAEC were treated with IFN- $\gamma$ before ( 48 -h IFN- $\gamma$ ), together with (24-h IFN- $\gamma$ ), or after ( 8-h IFN- $\gamma$ ) TNF- $\alpha$ addition ( $24 \mathrm{~h}$, $100 \mathrm{ng} / \mathrm{ml})$. A reasonable interpretation of the data presented thus far would be that a major effect of IFN- $\gamma$ is at the level of BAEC NO synthase activity in that the formation of biologically active NO and citrulline were both blunted.

Given that pretreatment of BAEC with $1,000 \mathrm{U} / \mathrm{ml}$ IFN- $\gamma$ completely blunted TNF- $\alpha$-stimulated $\mathrm{L}-\left[{ }^{14} \mathrm{C}\right]$ arginine conversion to $\mathrm{L}-\left[{ }^{14} \mathrm{C}\right]$ citrulline and TNF- $\alpha$-stimulated BAEC-dependent increases in reporter cGMP production, we studied the concentration dependency of IFN- $\gamma$-induced inhibition of TNF- $\alpha$ 's effect on $\mathrm{L}-\left[{ }^{14} \mathrm{C}\right]$ citrulline formation, where BAEC are treated for $48 \mathrm{~h}$ with IFN- $\gamma$ and for the final $24 \mathrm{~h}$ with TNF- $\alpha(100 \mathrm{ng} / \mathrm{ml})$. IFN- $\gamma$ inhibited L- $\left[{ }^{14} \mathrm{C}\right]$ citrulline production in TNF- $\alpha$-treated BAEC in a concentration-dependent manner over the range of $1-1,000 \mathrm{U} / \mathrm{ml}$ (Fig. 4). Half-maximal responses $\left(\mathrm{ED}_{50}\right)$ were estimated from log-logit transformation of the data and averaged $160 \pm 37 \mathrm{U} / \mathrm{ml}(n=3$, tripli-

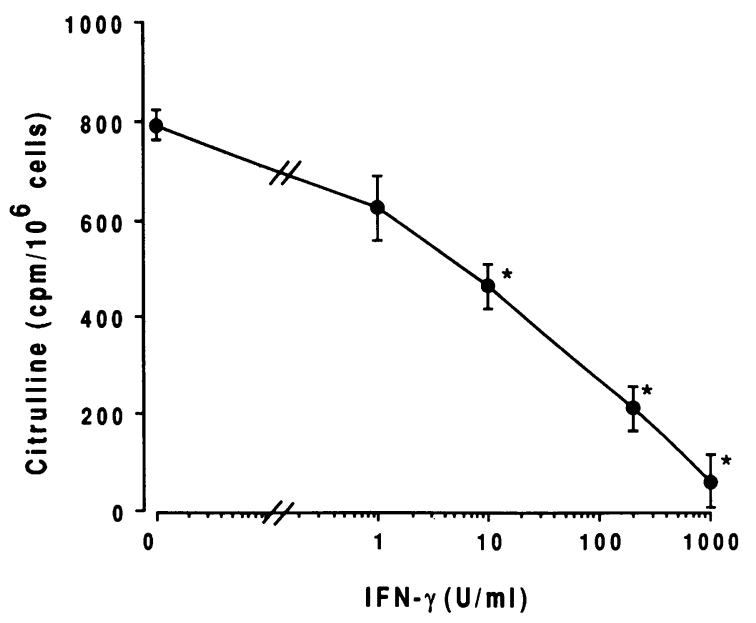

Figure 4. Concentration-response relationship for IFN- $\gamma$-induced inhibition of TNF- $\alpha$-stimulated $\mathrm{L}-\left[{ }^{14} \mathrm{C}\right]$ arginine to $\mathrm{L}-\left[{ }^{14} \mathrm{C}\right]$ citrulline conversion in BAEC. L- $\left[{ }^{14} \mathrm{C}\right]$ Arginine $\left(3 \times 10^{5} \mathrm{cpm} / \mathrm{ml}\right)$ was added for $3 \mathrm{~h}$ to BAEC grown in six-well plates. BAEC were treated with 100 $\mathrm{ng} / \mathrm{ml} \mathrm{TNF}-\alpha$ for $24 \mathrm{~h}$ and the indicated concentrations of IFN- $\gamma$ for $48 \mathrm{~h} . \mathrm{L}-\left[{ }^{14} \mathrm{C}\right]$ Citrulline in each well was determined by quantitative cation exchange chromatography. Each point represents means $\pm \mathrm{SE}$ of three experiments, triplicate determinations. ${ }^{*} P<0.05$ vs. TNF$\alpha$-treated BAEC in the absence of IFN- $\gamma$. 
cate determinations). Maximal inhibition of TNF- $\alpha$-induced increases in $\mathrm{L}-\left[{ }^{14} \mathrm{C}\right]$ citrulline formation in BAEC was observed at $1,000 \mathrm{U} / \mathrm{ml}$, whereas a threshold effect was observed at 1 $\mathrm{U} / \mathrm{ml}$. IFN- $\gamma$ exerted a similar concentration-dependent inhibitory effect on TNF- $\alpha$-stimulated $\mathrm{L}-\left[{ }^{14} \mathrm{C}\right]$ citrulline formation when TNF- $\alpha$ and IFN- $\gamma$ were added simultaneously to BAEC for $24 \mathrm{~h}$ (data not shown).

TNF- $\alpha$-stimulated increases in $\mathrm{L}-\left[{ }^{14} \mathrm{C}\right]$ citrulline were first evident at $8 \mathrm{~h}$ and increased over 24-48 h (15). Studies were designed to determine whether IFN- $\gamma$ modulated the time-dependent increase in BAEC NO synthase activity after TNF- $\alpha$ addition $(100 \mathrm{ng} / \mathrm{ml})$ as it was important to consider whether for any given period of IFN- $\gamma$ treatment the time course of NO synthase induction by TNF- $\alpha$ was modified. Fig. 5 illustrates $\mathrm{L}-\left[{ }^{14} \mathrm{C}\right]$ arginine conversion to $\mathrm{L}-\left[{ }^{14} \mathrm{C}\right]$ citrulline over a 3 -h period after TNF- $\alpha(100 \mathrm{ng} / \mathrm{ml})$ addition for 8,24 , and $48 \mathrm{~h}$ both in the presence and absence of $1,000 \mathrm{U} / \mathrm{ml} \mathrm{IFN}-\gamma$ for $24 \mathrm{~h}$. As described above, $24 \mathrm{~h}$ addition of IFN- $\gamma$ failed to exert a significant effect on $\mathrm{L}-\left[{ }^{14} \mathrm{C}\right]$ citrulline formation in the absence of TNF- $\alpha$. Shown in Fig. 5, treatment with IFN- $\gamma$ for $24 \mathrm{~h}$ inhibited BAEC L- $\left[{ }^{14} \mathrm{C}\right]$ citrulline formation regardless of the length of TNF- $\alpha$ treatment. Even when BAEC were treated for $48 \mathrm{~h}$ with TNF- $\alpha, 24-h$ treatment with IFN- $\gamma$ blunted NO synthase activity. Though not shown, a qualitatively similar time-dependent effect was evident after treatment of BAEC with concentrations of IFN- $\gamma$ approximating the $\operatorname{ED}_{50}(200 \mathrm{U} / \mathrm{ml})$.

IFN- $\gamma$ does not inhibit calcium-dependent NO synthase expression. BAEC do not metabolize $\mathrm{L}-\left[{ }^{14} \mathrm{C}\right]$ arginine to $\mathrm{L}-\left[{ }^{14} \mathrm{C}\right]-$ citrulline at significant rates under control conditions $(30)$. We have previously demonstrated that vehicle-treated BAEC pro-

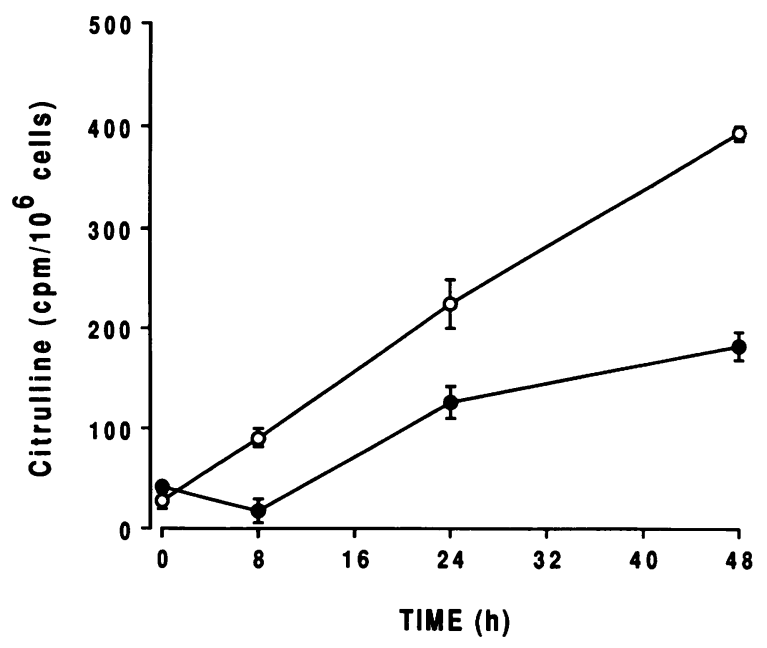

Figure 5. Effect of IFN- $\gamma$ on the time-dependent TNF- $\alpha$-induced augmentation of $\mathrm{L}-\left[{ }^{14} \mathrm{C}\right]$ arginine to $\mathrm{L}-\left[{ }^{14} \mathrm{C}\right]$ citrulline conversion in BAEC. L- $\left[{ }^{14} \mathrm{C}\right]$ Arginine $\left(3 \times 10^{5} \mathrm{cpm} / \mathrm{ml}\right)$ was added for $3 \mathrm{~h}$ to BAEC grown in six-well plates. $\mathrm{L}-\left[{ }^{14} \mathrm{C}\right]$ Citrulline production in each well was determined by quantitative cation exchange chromatography. BAEC were treated with $100 \mathrm{ng} / \mathrm{ml} \mathrm{TNF-} \alpha$ for 8,24 , and $48 \mathrm{~h}$ in the absence (O) or presence of $1,000 \mathrm{U} / \mathrm{ml} \mathrm{IFN}-\gamma$ for $24 \mathrm{~h}(\bullet)$. Each point represents mean \pm SEM from one of three representative experiments, triplicate determinations. The two curves are different by ANOVA $(P<0.05)$. Where error bars are not evident, SE was smaller than data point. duce significant amounts of $\mathrm{L}-\left[{ }^{14} \mathrm{C}\right]$ citrulline in the presence of calcium ionophore, that TNF- $\alpha$-treated BAEC produce significant amounts of $\mathrm{L}-\left[{ }^{14} \mathrm{C}\right]$ citrulline in the absence of calcium ionophore, and that $\mathrm{L}-\left[{ }^{14} \mathrm{C}\right]$ citrulline production in the presence of both TNF- $\alpha$ and calcium ionophore is additive. These data were taken to indicate that TNF- $\alpha$-induced and $\mathrm{Ca}^{2+}-\mathrm{ac}$ tivated NO synthase activity in BAEC are independent enzymatic processes. This interpretation is consistent with recent work from other laboratories (16). Table I demonstrates the effect of calcium ionophore (A23187, $10 \mu \mathrm{M}, 15 \mathrm{~min}$ ) on $\mathrm{L}$ $\left[{ }^{14} \mathrm{C}\right]$ citrulline formation in BAEC in the absence and presence of IFN- $\gamma(1,000 \mathrm{U} / \mathrm{ml}, 48 \mathrm{~h})$. It is evident that A23187 still induced increases in $\mathrm{L}-\left[{ }^{14} \mathrm{C}\right]$ arginine conversion to $\mathrm{L}$ $\left[{ }^{14} \mathrm{C}\right]$ citrulline in IFN- $\gamma$-treated BAEC.

NO release from vascular endothelial cells is stimulated by calcium-mobilizing agonists. Therefore, we further determined the effect of IFN- $\gamma$ on calcium/calmodulin-dependent release of bioactive NO. Addition of bradykinin ( $100 \mathrm{nM}, 2 \mathrm{~min}$ ) to the coincubation assay significantly augmented BAEC-dependent mesangial cell-associated cGMP content, a response not modified by IFN- $\gamma(200 \mathrm{U} / \mathrm{ml}, 24 \mathrm{~h})(50 \pm 6,40 \pm 5,86 \pm 10$, and $76 \pm 8 \mathrm{fmol} \mathrm{cGMP} / 10^{6}$ mesangial cells in the presence of vehicle-, IFN- $\gamma-$, bradykinin-, and IFN- $\gamma /$ bradykinintreated BAEC, respectively ( $n=3$, triplicate determinations, $P$ $<0.05$ for vehicle- vs. bradykinin- or IFN- $\gamma /$ bradykinintreated BAEC). In these experiments cGMP content was $30 \pm 5$ fmol cGMP $/ 10^{6}$ mesangial cells in the absence of endothelial cells.

Effect of IFN- $\gamma$ on TNF- $\alpha$-stimulated increases in ET-1 expression. Shown in Fig. $6 \mathrm{~A}$ are results of ET measurements in medium conditioned by BAEC for an 8-h interval. After a change of medium, BAEC were treated with vehicle, IFN- $\gamma$ $(1,000 \mathrm{U} / \mathrm{ml})$, TNF- $\alpha(100 \mathrm{ng} / \mathrm{ml})$ or both IFN- $\gamma$ and TNF- $\alpha$ for $8 \mathrm{~h}$ and medium was collected for quantitation of ET content. Compared to vehicle-treated cells, ET levels were significantly greater in the medium of BAEC treated with TNF- $\alpha$. IFN- $\gamma$ failed to have a significant effect by itself, but potentiated the stimulatory effect of TNF- $\alpha$ on ET release.

It was of interest to determine whether pretreatment of BAEC monolayers with IFN- $\gamma$ modified TNF- $\alpha$-stimulated in-

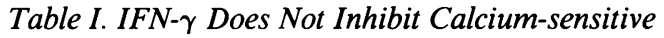
NO Synthase Activity

\begin{tabular}{ll}
\hline \multicolumn{1}{c}{ Treatment } & \multicolumn{1}{c}{ Citrulline } \\
\hline & cpm/10 cells \\
Vehicle & $427 \pm 5$ \\
A23187 & $-937 \pm 49^{*}$ \\
IFN- $\gamma$ and A23187 & $750 \pm 90^{*}$
\end{tabular}

Effect of IFN- $\gamma$ on calcium ionophore (A23187)-induced augmentation of $\mathrm{L}-\left[{ }^{14} \mathrm{C}\right]$ arginine to $\mathrm{L}-\left[{ }^{14} \mathrm{C}\right]$ citrulline conversion in BAEC. $\mathrm{L}-$ $\left[{ }^{14} \mathrm{C}\right]$ Arginine $\left(3 \times 10^{5} \mathrm{cpm} / \mathrm{ml}\right)$ was added for $3 \mathrm{~h}$ to BAEC grown in six-well plates. $\mathrm{L}-\left[{ }^{14} \mathrm{C}\right]$ Citrulline formation in BAEC treated with vehicle, A23187 (10 $\mu \mathrm{M}, 15 \mathrm{~min})$, or both INF- $\gamma(1,000 \mathrm{U} / \mathrm{ml}, 48 \mathrm{~h})$ and A23187 was determined by quantitative cation-exchange chromatography. Data the mean $\pm \mathrm{SE}$ of three separate experiments. ${ }^{*} P$ $<0.05$ vs. vehicle-treated BAEC. 
creases in ET release. Shown in Fig. $6 B$ are results of measurements of ET in medium conditioned by BAEC for an 8-h interval after a 16-h prior incubation with $\operatorname{IFN}-\gamma(1,000 \mathrm{U} / \mathrm{ml}, 16$ h). For these studies BAEC were treated with IFN- $\gamma$ or vehicle for $16 \mathrm{~h}$. The medium was discarded, and fresh medium containing cytokines was added. After a conditioning period of $8 \mathrm{~h}$, medium was collected for quantitation of ET content. As shown, prior incubation with IFN- $\gamma$ for $16 \mathrm{~h}$ failed to exert a significant effect on ET release from BAEC over an 8-h period. In contrast, pretreatment of BAEC with IFN- $\gamma$ attenuated the subsequent stimulatory effect of 8-h TNF- $\alpha$ treatment (compare 8-h TNF- $\alpha$ with $24-\mathrm{h}$ IFN- $\gamma / 8$-h TNF- $\alpha$ ). Thus, concurrent treatment with IFN- $\gamma$ potentiates the effect of TNF- $\alpha$ on ET release whereas pretreatment with IFN- $\gamma$ inhibits TNF- $\alpha-$ induced increases in ET release.
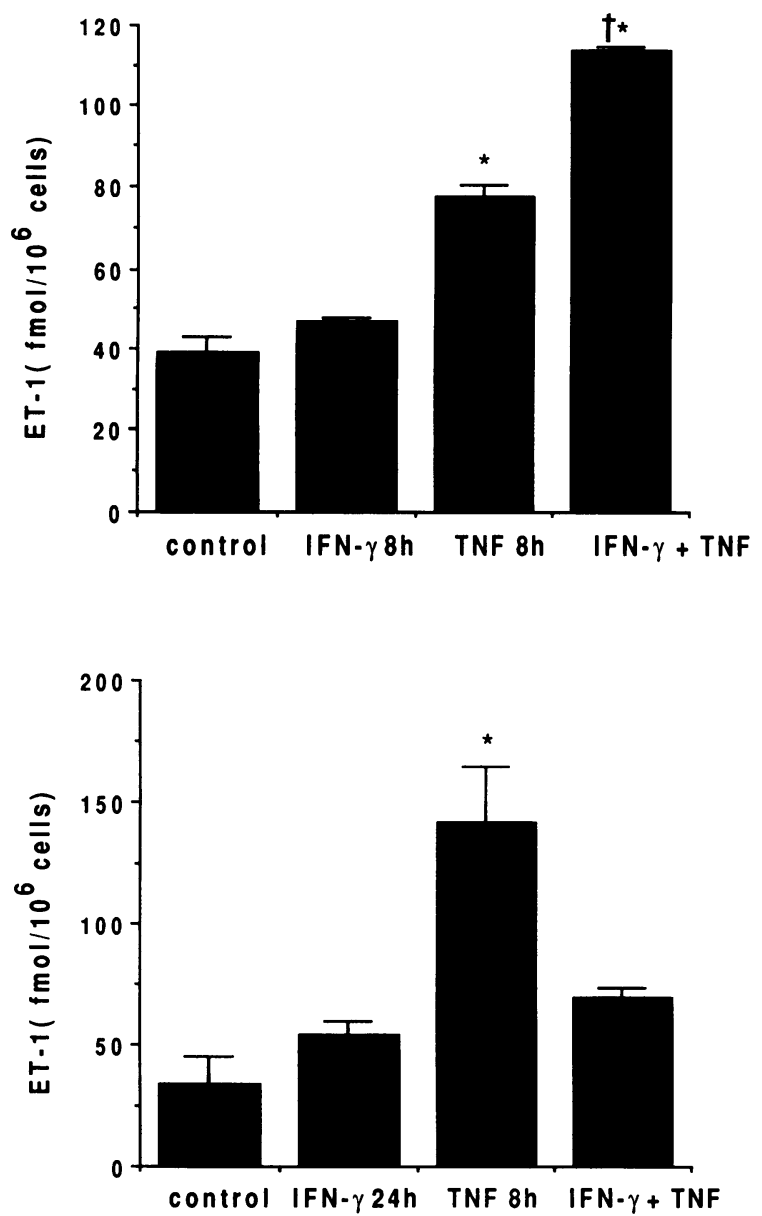

Figure 6. IFN- $\gamma$ modulation of TNF- $\alpha$-induced increases in ET release from BAEC. $(A)$ Measurement of ET in BAEC medium after addition of vehicle (control), IFN- $\gamma(1,000 \mathrm{U} / \mathrm{ml}, 8 \mathrm{~h}), \mathrm{TNF}-\alpha(100$ $\mathrm{ng} / \mathrm{ml}$ ) or both IFN- $\gamma$ and TNF- $\alpha$ for $8 \mathrm{~h}$. Data represent mean \pm SE from one of three representative experiments, triplicate determinations. ${ }^{*} P<0.05$ vs. control. ${ }^{\dagger} P<0.05$ vs. TNF- $\alpha$-treated BAEC. $(B)$ ET-1 content of medium conditioned by BAEC $16-24 \mathrm{~h}$ after pretreatment with vehicle or IFN- $\gamma(1,000 \mathrm{U} / \mathrm{ml})$ for $16 \mathrm{~h}$. Cells pretreated with vehicle or IFN- $\gamma$ were treated with vehicle or TNF- $\alpha$ for the final $8 \mathrm{~h}$. Data represent mean $\pm \mathrm{SE}$ from one of three representative experiments, triplicate determinations. ${ }^{*} P<0.05$ vs. control.

B
Cultured endothelial cells do not contain a storage pool of ET-1 and synthesis of endothelial ET-1 is regulated primarily at the level of transcription (31). Given that IFN- $\gamma$ modified the effects of TNF- $\alpha$ on release of ET from BAEC we evaluated the effect of IFN- $\gamma$ on steady-state levels of preproET-1 mRNA by northern analysis. Hybridization of size-fractionated BAEC RNA with a ${ }^{32} \mathrm{P}$-labeled bovine preproET-1 cDNA detected a single 2.3-kb transcript. Fig. $7 A$ demonstrates results of a representative Northern blot of BAEC treated for $4 \mathrm{~h}$ with vehicle (lane 1$), \operatorname{IFN}-\gamma(1,000 \mathrm{U} / \mathrm{ml})$ (lane 2$), \mathrm{TNF}-\alpha(100 \mathrm{ng} / \mathrm{ml})$ (lane 3), or IFN- $\gamma$ and TNF- $\alpha$ (lane 4). TNF- $\alpha$ increased steady state levels of preproET-1 mRNA in BAEC as described previously (22), whereas IFN- $\gamma$ failed to have a significant effect on mRNA transcript levels. Consistent with measurements of ET in conditioned medium, IFN- $\gamma$ potentiated the stimulatory effect of TNF- $\alpha$ on preproET-1 mRNA levels in BAEC (compare lane 4 with lane 3 ). Shown in the lower panel of Fig. $7 A$, reprobing of the nylon membranes with a rat $\beta$-tubulin cDNA confirmed equivalent amounts of RNA for each treatment condition. Values derived from a densitometric analysis of the amount of preproET-1 mRNA transcript, expressed relative to control levels and corrected for the amount of rat $\beta$-tubulin transcript per lane, for this representative experiment were $1,1.2,3.1$, and 10 for vehicle, IFN- $\gamma(4 \mathrm{~h}), \operatorname{TNF}-\alpha(4 \mathrm{~h})$, and IFN- $\gamma /$ TNF- $\alpha$ (both $4 \mathrm{~h}$ ), respectively.

Shown in Fig. $7 B$, pretreatment of BAEC with IFN- $\gamma$ failed to have a significant effect on preproET-1 transcript level but inhibited TNF- $\alpha$-stimulated increases in steady-state mRNA levels of preproET-1 (compare lane 4 with lane 3 ). Equivalent expression of $\beta$-tubulin confirmed that the amount of RNA loaded per lane was equal for each condition. Values derived from a densitometric analysis of the amount of preproET-1

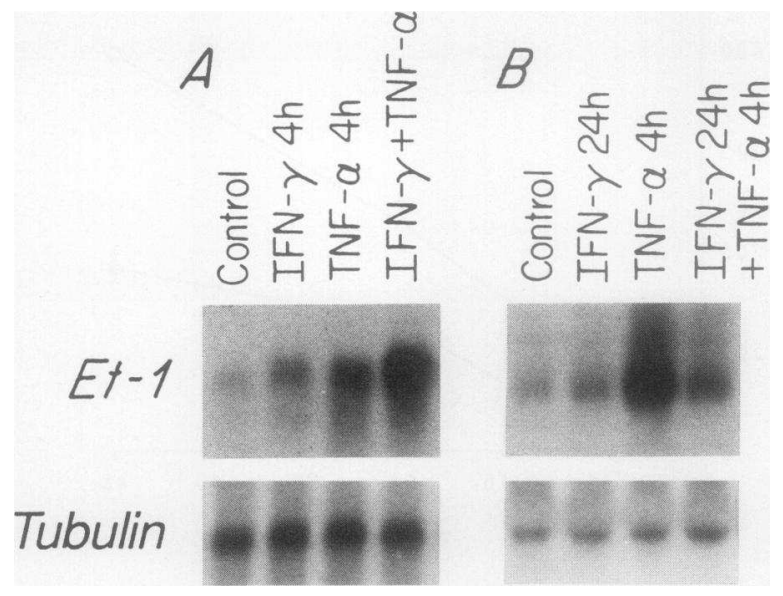

Figure 7. Effect of IFN- $\gamma$ on preproET-1 mRNA expression. $(A)$ Northern blot of total cellular RNA ( $10 \mu \mathrm{g}$ per lane) isolated from BAEC treated for $4 \mathrm{~h}$ with vehicle (lane 1$), \operatorname{IFN}-\gamma(1,000 \mathrm{U} / \mathrm{ml})$ (lane 2), TNF- $\alpha(100 \mathrm{ng} / \mathrm{ml}$ ) (lane 3), or both (lane 4). (B) BAEC were treated with vehicle or IFN- $\gamma(1,000 \mathrm{U} / \mathrm{ml})$ for $24 \mathrm{~h}$ cells in the presence of vehicle or TNF- $\alpha(100 \mathrm{ng} / \mathrm{ml})$ for the final $4 \mathrm{~h}$ before extraction of total cellular RNA. Membranes were probed with a ${ }^{32} \mathrm{P}$ labeled bovine ET-1 cDNA. In the lower panels nylon membranes were reprobed with a ${ }^{32} \mathrm{P}$-labeled rat $\beta$-tubulin cDNA. Shown are representative data of three independent experiments. 
mRNA transcript, expressed relative to control levels and corrected for the amount of rat $\beta$-tubulin transcript per lane, for this representative experiment were $1,1.2,8$, and 1.8 for vehicle, IFN- $\gamma(24 \mathrm{~h})$, TNF- $\alpha(4 \mathrm{~h})$, and IFN- $\gamma(24 \mathrm{~h}) / \mathrm{TNF}-\alpha$ $(4 \mathrm{~h})$, respectively. Again, these results are consistent with measurements of ET in the conditioned medium of BAEC.

\section{Discussion}

Recent studies have demonstrated that endothelial cells play a significant role in the inflammatory response, expressing a broad repertoire of constitutive and inducible effector functions $(19,32)$. Cytokine modulation of endothelial phenotype in vitro recapitulates many of the phenomena observed during the inflammatory response in vivo. For example, proinflammatory cytokines, such as TNF- $\alpha$, which are known to induce profound alterations in vascular wall function, modulate the production of two potent vasoactive mediators released by vascular endothelium, NO and ET-1.

Results from several laboratories, including our own, indicate that, although endothelial cells constitutively express calcium/calmodulin-dependent NO synthase activity, they can be induced by cytokines to express a calcium-independent NO synthase isoform(s) $(15,16,33)$. NO produced in the former pathway may play an important role in the local dynamic control of vascular tone (34), whereas the latter pathway has been suggested as important in inflammation (13), immune injury (35), and pathophysiologic control of local blood flow (33, 36). An important concept that follows from this dual process is the possibility that basal release of endothelial-derived NO within various organ beds reflects NO released from two possible regulatory pathways, both of which would be sensitive to inhibition by substituted L-arginine analogues. Whether the vascular endothelium of unique organ beds can express significant basal amounts of NO derived from calcium-independent NO synthase requires further study. Elucidation of the regulatory mechanisms for inducible calcium-independent NO synthase expression in vascular endothelium represents an important aspect of these studies. In a previous study (15) we demonstrated that TNF- $\alpha$ enhanced L-arginine-dependent synthesis of NO and L-citrulline in bovine aortic endothelial cells. That study addressed the effect of an individual cytokine. In keeping with current models of immune activation, it is becoming increasingly evident that cytokines operate in a fashion wherein interactions among several specific cytokines can occur. A major aim of the current study was to determine the effect of IFN- $\gamma$ on NO synthase activity in bovine endothelial cells.

Though IFN- $\gamma$ failed to exert a significant effect on basal release of $\mathrm{NO}$ or metabolic conversion of $\mathrm{L}-\left[{ }^{14} \mathrm{C}\right]$ arginine to $\mathrm{L}-\left[{ }^{14} \mathrm{C}\right]$ citrulline, the addition of IFN- $\gamma$ to BAEC markedly inhibited TNF- $\alpha$-stimulated increases in release of bioactive NO or $\mathrm{L}-\left[{ }^{14} \mathrm{C}\right]$ arginine conversion to $\mathrm{L}-\left[{ }^{14} \mathrm{C}\right]$ citrulline. The capacity for IFN- $\gamma$ to antagonize TNF- $\alpha$-stimulated induction of NO synthase activity in BAEC was most pronounced when cells were pretreated with IFN- $\gamma$. Measured under these conditions, IFN- $\gamma$ decreased TNF- $\alpha$-stimulated formation of $L$ $\left[{ }^{14} \mathrm{C}\right]$ citrulline in a concentration-dependent manner over the range of $1-1,000 \mathrm{U} / \mathrm{ml} . \mathrm{ED}_{50}$ responses averaged $160 \pm 37 \mathrm{U} /$ $\mathrm{ml}$, with threshold effects and maximal inhibition observed at 1 and $1,000 \mathrm{U} / \mathrm{ml}$, respectively. The ability of IFN- $\gamma$ pretreat- ment to abrogate TNF- $\alpha$-stimulated increases in BAEC NO synthase activity could not be explained by cellular toxicity. Though minor increases in LDH release and trypan blue staining were evident, as has been described previously in human umbilical vein endothelium (37), the magnitude of the observed toxic changes were trivial compared with the complete inhibition of inducible NO synthase activity evident when cells were treated with the combination of IFN- $\gamma$ for $48 \mathrm{~h}$ and TNF$\alpha$ for 24 h. Furthermore, TNF- $\alpha$-stimulated increases in BAEC NO synthase activity were also inhibited when IFN- $\gamma$ was added together with, or after, TNF- $\alpha$.

Although IFN- $\gamma$ inhibited TNF- $\alpha$-stimulated induction of BAEC NO synthase activity, IFN- $\gamma$ did not inhibit A23187-stimulated $\mathrm{L}-\left[{ }^{14} \mathrm{C}\right]$ citrulline formation or bradykinininduced BAEC-dependent increases in reporter monolayer cGMP content. This evidence suggests that calcium-sensitive NO synthase activity is not affected. We recognize that further studies will be necessary to characterize the nature of the NO synthase isoform(s) modulated by IFN- $\gamma$. Nonetheless, the most reasonable interpretation of our observations is that IFN$\gamma$ inhibits the induction of calcium-independent NO synthase activity. IFN- $\gamma$ did not inhibit activity of the calcium/calmodulin-dependent NO synthase. This is a surprising observation in that IFN- $\gamma$ synergizes with TNF- $\alpha$ or LPS to induce NO synthase activity in murine macrophages $(6,38,39)$. It is apparent that the cellular effects of IFN- $\gamma$ on NO production and action are complex. Leu et al. (40) provided evidence that production of $\mathrm{NO}_{2}^{-}$, an end product of NO metabolism, by LPStreated murine macrophages was greater when macrophages were cocultured with IFN- $\gamma$-treated L1210 tumor target cells than when macrophages were cocultured with IFN- $\gamma$-treated P815 tumor targets. IFN- $\gamma$ appeared to have an opposite effect dependent upon the tumor cell type studied. It is apparent that much remains to be learned about cell type-specific regulation of the inducible, calcium-independent NO synthase(s).

The striking finding in the current study is that IFN- $\gamma$ abrogated TNF- $\alpha$-induced increases in NO synthase activity in vascular endothelium. Similarly, glucocorticoids also inhibit expression of the inducible form of NO synthase in endothelial cells without modulating the activity of calcium/calmodulindependent NO synthase (16). The mechanism(s) whereby IFN- $\gamma$ and glucocorticoids inhibit expression of the calciumindependent endothelial NO synthase remain to be determined. Radomski et al. (16) reported that glucocorticoids fail to inhibit endothelial NO synthase in porcine aortic endothelial cells once enzymatic activity was induced by LPS and cytokines. In contrast, evidence presented here indicates that IFN- $\gamma$ can inhibit NO production even when BAEC are pretreated with TNF- $\alpha$. It is of great interest that endogenous cytokines can inhibit the induction of calcium-independent NO synthase; TGF- $\beta$ inhibits the induction of enzymatic activity in macrophages and mesangial cells $(13,41)$, IL-8 inhibits the induction of neutrophil NO synthase (42), and in the present study IFN- $\gamma$ inhibits induction of bovine endothelial NO synthase activity. The recent cloning and characterization of bovine (43) and human (44) constitutive endothelial NO synthase complementary DNA clones provide valuable reagents to pursue the molecular mechanisms underlying regulated expression of NO by endothelial cells.

A second major aim of the current study was to determine 
the effect of IFN- $\gamma$ on ET- 1 expression by BAEC. We found that IFN- $\gamma$ potentiated the stimulatory effect of TNF- $\alpha$ on ET1 release and preproET-1 mRNA accumulation in BAEC over a 4-8-h period. Consistent with our studies on endothelial NO synthase activity, IFN- $\gamma$ alone failed to have a significant effect on ET-1 expression in the absence of concurrent TNF- $\alpha$ treatment. The results of Northern blot analyses indicate that IFN- $\gamma$ mediates this effect, in part, by potentiating TNF- $\alpha$-stimulated increases in preproET-1 mRNA expression. Whether this potentiation is at the level of transcription or is mediated by stabilization of TNF- $\alpha$-induced mRNA transcripts remains to be determined. Viewed in the context of the above mentioned studies one could conclude that cotreatment of BAEC with IFN- $\gamma$ and TNF- $\alpha$ would potentiate ET- 1 expression over 4-8 $h$, but inhibit TNF- $\alpha$-stimulated induction of NO synthase activity at $24 \mathrm{~h}$.

Studies were designed to determine whether pretreatment of BAEC with IFN- $\gamma$ modified the effect of TNF- $\alpha$ on endothelial ET-1 expression. We found that pretreatment of BAEC with IFN- $\gamma$ antagonizes the stimulatory effect of TNF- $\alpha$ on ET-1 release and preproET-1 mRNA expression. These results are in marked contrast to the synergy observed when these cytokines were added simultaneously. These findings are of interest in that the potential for synergy or antagonism appears to be dependent upon the chronology of cytokine exposure.

These data demonstrate that IFN- $\gamma$ alone fails to exert a significant effect on endothelial expression of the potent vasomediators NO and ET- 1 . In contrast, IFN- $\gamma$ exerts a potent inhibitory effect on TNF- $\alpha$-stimulated induction of NO synthase activity and NO release but does not modify calcium-dependent NO release. IFN- $\gamma$ also potentiates TNF- $\alpha$-stimulated induction of ET-1 expression when added concurrently, whereas pretreatment with IFN- $\gamma$ blunts the effect of TNF- $\alpha$. Such findings suggest that endothelial cell expression of vasoactive mediators is modified by the temporal interplay of at least two immune mediators, IFN- $\gamma$ and TNF- $\alpha$. The relevance of these findings to the hemodynamic perturbations that characterize septic shock remains to be established.

\section{Acknowledgments}

We thank Knoll Pharmaceuticals, Whippany, NJ, for supplying rHuTNF- $\alpha$ and CIBA-GEIGY, Basel, Switzerland for supplying rBoIFN- $\gamma$.

Dr. Santiago Lamas is a fellow of the Fulbright Foundation-Ministerio de Educación y Ciencia, Spain and supported in part by the Spanish Society of Nephrology. Dr. Thomas Michel is a recipient of a Clinician Scientist Award from the American Heart Association. Dr. Tucker Collins is an established investigator of the American Heart Association. This study was supported by National Institutes of Health grant DK-35930 and the Medical Research Council of Canada.

\section{References}

1. Vane, J. R., E. E. Anggard, and R. M. Botting. 1990. Regulatory functions of the vascular endothelium. N. Engl. J. Med. 323:27-36.

2. Nathan, C. F., and D. J. Stuehr. 1990. Does endothelium-derived nitric oxide have a role in cytokine-induced hypotension? J. Natl. Cancer Inst. 82:726728.

3. Bredt, D. S., and S. H. Snyder. 1990. Isolation of nitric oxide synthetase, a calmodulin-requiring enzyme. Proc. Natl. Acad. Sci. USA. 87:682-685.

4. Bredt, D. S., P. M. Hwang, C. E. Glatt, C. Lowenstein, R. R. Reed, and
S. H.Snyder. 1991. Cloned and expressed nitric oxide synthase structurally resembles cytochrome P-450 reductase. Nature (Lond.). 351:714-718.

5. Palmer, R. M. J., and S. Moncada. 1989. A novel citrulline-forming enzyme implicated in the formation of nitric oxide by vascular endothelial cells. Biochem. Biophys. Res. Commun. 158:348-352.

6. Hibbs, J. B. J., R. R. Taintor, Z. Vavrin, and E. M. Rachlin. 1988. Nitric oxide: a cytotoxic activated macrophage effector molecule. Biochem. Biophys. Res. Commun. 157:87-94.

7. Stuehr, D. J., and M. A. Marletta. 1987. Synthesis of nitrite and nitrate in murine macrophage cell lines. Cancer Res. 47:5590-5594.

8. McCall, T., N. K. Broughton-Smith, R. M. J. Palmer, B. J. R. Whittle, and S. Moncada. 1989. Synthesis of nitric oxide from L-arginine by neutrophils. Release and interaction with superoxide anion. Biochem. J. 261:293-296.

9. Billiar, T. R., R. D. Curran, D. J. Stuehr, M. A. West, et al. 1989. An L-arginine-dependent mechanism mediates kupffer cell inhibition of hepatocyte protein synthesis in vitro. J. Exp. Med. 169:1467-1472.

10. Curran, R. D., T. R. Billiar, D. J. Stuehr, M. A. West, B. G. Bentz, and R. L. Simmons. 1989. Hepatocytes produce nitrogen oxides from L-arginine in response to inflammatory products of Kupffer cells. J. Exp. Med. 170:1176911774.

11. Beasley, D., J. H. Schwartz, and B. M. Brenner. 1991. Interleukin-1 induces prolonged L-arginine-dependent cyclic guanosine monophosphate and nitrite production in rat vascular smooth muscle. J. Clin. Invest. 87:602-608.

12. Busse, R., and A. Mulsch. 1990. Induction of nitric oxide synthase by cytokines in vascular smooth muscle cells. FEBS (Fed. Eur. Biochem. Soc.) Lett. 275:87-90.

13. Marsden, P. A., and B. J. Ballermann. 1990. Tumor necrosis factor activates soluble guanylate cyclase in bovine glomerular mesangial cells via an L-arginine-dependent mechanism. J. Exp. Med. 172:1843-1852.

14. Pfeilschifter, J., and H. Schwarzenbach. 1990. Interleukin 1 and tumor necrosis factor stimulate cGMP formation in rat renal mesangial cells. FEBS (Fed. Eur. Biochem. Soc.) Lett. 273:185-187.

15. Lamas, S., T. Michel, B. M. Brenner, and P. A. Marsden. 1991. EDRF synthesis by endothelial cells: evidence for a pathway induced by TNF- $\alpha$. Am. J. Physiol. (Cell. Physiol.). 261:C634-C641.

16. Radomski, M. W., R. M. J. Palmer, and S. Moncada. 1990. Glucocorticoids inhibit the expression of an inducible, but not constitutive, nitric oxide synthase in vascular endothelial cells. Proc. Natl. Acad. Sci. USA. 87:1004310047.

17. Kilbourn, R. G., S. S. Gross, A. Jubran, J. Adams, O. W. Griffeth, R. Levi, and R. F. Lodato. 1990. $\mathrm{N}^{\mathrm{B}}$-methyl-L-arginine inhibits tumor necrosis factor-induced hypotension: implications for the involvement of nitric oxide. Proc. Natl. Acad. Sci. USA. 87:3629-3632.

18. Thiemermann, C., and J. Vane. 1990. Inhibition of nitric oxide synthesis reduces the hypotension induced by bacterial lipopolysaccharides in the rat in vivo. Eur. J. Pharmacol. 182:591-595.

19. Pober, J. S., and R. S. Cotran. 1990. Cytokines and endothelial cell biology. Physiol. Rev. 70:427-451.

20. Yanagisawa, M., H. Kurihara, S. Kimura, Y. Tomobe, M. Kobayashi, Y. Mitsui, Y. Yasake, K. Goto, and T. Masaki. 1988. A novel potent vasoconstrictor peptide produced by vascular endothelial cells. Nature (Lond.). 332:411-415.

21. Kurihara, H., M. Yoshizumi, T. Sugiyama, F. Takakku, M. Yanagisawa, T. Masaki, M. Hamoaki, H. Kato, and Y. Yazaki. 1989. Transforming growth factor- $\beta$ stimulates the expression of endothelin mRNA by vascular endothelial cells. Biochem. Biophys. Res. Commun. 159:1435-1440.

22. Marsden, P. A., and B. M. Brenner. 1992. Transcriptional regulation of endothelin-1 by tumor necrosis factor-alpha. Am. J. Physiol. (Cell.). 262:C854C861.

23. Yoshizumi, M., H. Kurihara, T. Morita, T. Yamashita, Y. Oh-hashi, T. Sugiyama, F. Takaku, M. Yanagisawa, T. Masaki, and Y. Yazaki. 1990. Interleukin 1 increases the production of endothelin-1 by cultured endothelial cells. Biochem. Biophys. Res. Commun. 166:324-329.

24. Sugiura, M., T. Inagami, and V. Kon. 1989. Endotoxin stimulates endothelin-release in vivo and in vitro as determined by radioimmunoassay. Biochem. Biophys. Res. Commun. 161:1220-1227.

25. Marsden, P. A., T. A. Brock, and B. J. Ballermann. 1990. Glomerular endothelial cells respond to calcium-mobilizing agonists with release of EDRF. Am. J. Physiol. (Renal Fluid Electrolyte). 258:F1295-F1303.

26. Marsden, P. A., D. M. Dorfman, T. Collins, B. M. Brenner, S. H. Orkin, and B. J. Ballermann. 1991. Regulated expression of endothelin-1 in bovine glomerular endothelial cells. Am. J. Physiol. (Renal Fluid Electrolyte). 261:F117-F125.

27. Chomczynski, P., and N. Sacchi. 1987. Single-step method of RNA isolation by guanidinium thiocyanate-phenol-chloroform extraction. Anal. Biochem. 162:156-159.

28. Elshourbagy, N. A., P. Kmetz, and G. M. Sathe. 1990. Nucleotide sequence of endothelin cDNA from bovine endothelial cells. Nucleic Acids Res. 18:4273. 
29. Bond, F. F., and S. R. Farmer. 1983. Regulation of tubulin and actin mRNA production in rat brain: expression of new $\beta$-tubulin mRNA with development. Mol. Cell. Biol. 3:1333.

30. Hecker, M., W. C. Sessa, H. J. Harris, E. E. Anggard, and J. R. Vane. 1990. The metabolism of $L$-arginine and its significance for the biosynthesis of endothelium-derived relaxing factor: cultured endothelial cells recycle L-citrulline to L-arginine. Proc. Natl. Acad. Sci. USA. 87:8612-8616.

31. Yanagisawa, M., and T. Masaki. 1989. Molecular biology and biochemistry of the endothelins. Trends Pharmacol. Sci. 10:374-378.

32. Cotran, R., and J. Pober. 1989. Effects of cytokines on vascular endothelium: their role in vascular and immune injury. Kidney Int. 335:969-975.

33. Kilbourn, R. G., A. Jubran, S. S. Gross, O. W. Griffeth, R. Levi, J. Adams, and R. F. Lodato. 1990. Reversal of endotoxin-mediated shock by $\mathrm{N}^{3}$-methyl-Larginine, an inhibitor of nitric oxide synthesis. Biochem. Biophys. Res. Commun. 172:1132-1138.

34. Moncada, S., R. M. J. Palmer, and E. A. Higgs. 1989. Biosynthesis of nitric oxide from L-arginine. A pathway for the regulation of cell function and communication. Biochem. Pharmacol. 38:1709-1715.

35. Li, L., R. G. Kilbourn, J. Adams, and I. J. Fidler. 1991. Role of nitric oxide in lysis of tumor cells by cytokine-activated endothelial cells. Cancer Res. 51:2531-2535.

36. Knowles, R. G., M. Salter, S. L. Brooks, and S. Moncada. 1990. Anti-inflammatory glucocorticoids inhibit the induction by endotoxin of nitric oxide synthase in the lung, liver and aorta of the rat. Biochem. Biophys. Res. Commun. 172:1042-1048.
37. Friesel, R., A. Komoriya, and T. Maciag. 1987. Inhibition of endothelial cell proliferation. J. Cell Biol. 104:689-696.

38. Stuehr, D. J., and C. F. Nathan. 1989. Nitric Oxide: A macrophage product responsible for cytostasis and respiratory inhibition in tumor target cells. $J$. Exp. Med. 169:1543-1555.

39. Kwon, N. S., C. F. Nathan, C. Gilker, O. W. Griffith, et al. 1990. L-Citrulline production from L-arginine by macrophage nitric oxide synthase. J. Biol. Chem. 265:13442-13445.

40. Leu, R. W., N. R. Leu, B. J. Shannon, and D. J. Fast. 1991. IFN- $\gamma$ differentially modulates the susceptibility of L1210 and P815 tumor targets for macrophage-mediated cytotoxicity. J. Immunol. 147:1816-1822.

41. Ding, A., C. F. Nathan, J. Graycar, R. Derynck, D. J. Stuehr, and S. Srimal. 1990. Macrophage deactivating factor and transforming growth factors$\beta_{1},-\beta_{2}$, and $-\beta_{3}$ inhibit induction of macrophage nitrogen oxide synthesis by IFN- $\gamma$. J. Immunol. 145:940-945.

42. McCall, T. B., R. M. J. Palmer, and S. Moncada. 1991. Induction of nitric oxide (NO) synthase in rat peritoneal neutrophils (PMN) and its inhibition by dexamethasone and the cytokine interleukin (IL)-8. In Proceedings, 2nd International Meeting Biology of Nitric Oxide. Waverly Press, Baltimore, MD. (Abstr.)

43. Lamas, S., P. A. Marsden, G. K. Li, P. Tempst, and T. Michel. 1992. Endothelial nitric oxide synthase: molecular cloning and characterization of a distinct constitutive enzyme isoform. Proc. Natl. Acad. Sci. USA. 89:6348-6352.

44. Marsden, P. A., K. T. Schappert, H. S. Chen, M. Flowers, C. L. Sundell, J. N. Wilcox, S. Lamas, and T. Michel. 1992. Molecular cloning and characterization of human endothelial nitric oxide synthase. FEBS (Fed Eur. Biochem. Soc.) Lett. 307:287-293. 